\title{
Leicester's Men and the Lost Telomo of 1583
}

\begin{abstract}
This article proposes a new identification for the lost play Telomo, performed at court by Leicester's Men in 1583. Challenging previous hypotheses that the play might have been either about a character named Ptolemy or about one of the main character's friends from the Spanish romance Palmerin d'Oliva, this article suggests that the play may have dramatized either episodes involving Ajax Telamonius or his father or, as appears more likely, the episode of 'The Vnkindly Loue of Telamon to Castibula His Frends Wife' from Brian Melbancke's euphuistic romance Philotimus. The Warre betwixt Nature and Fortune (1583).
\end{abstract}

\section{The State of the Art}

On 10 February 1583, the Accounts of the Office of the Revels record a court performance of

A historie of Telomo shewed before her maiestie at Richmond on Shrovesondaie at night Enacted by the Earle of Leicesters servauntes, for which was prepared and Imployed, one Citty, one Battlement of canvas iij. Ells of sarcenet and viij. paire of gloves. And furnished with sondrey other garmentes of the store of the office \&c. ${ }^{1}$

No further information is available about the play, and no script or fragment is extant. Nonetheless, as Sally-Beth MacLean observes, for the members of Leicester's Men who had secured the royal patent in 1574 this performance must have been one of the last before some of the company joined the newly-formed Queen's Men in March 1583. ${ }^{2}$

As is the case with the majority of lost plays - that is, '(putative) play[s] for which there survives some evidence, but not a full playscript', in Matthew

Domenico Lovascio (lovascio.domenico@gmail.com) is ricercatore in English literature in the department of Modern Languages and Cultures at the University of Genoa and was a visiting scholar at Sheffield Hallam University in 2016. 
Steggle's felicitous definition - any investigation into the nature and contents of Telomo has to start from an enquiry into its title, a document of performance that is 'the briefest, the most primitive, and often the most densely meaningful member of the loose family of textual forms that together make up an early modern play'. ${ }^{3}$ Steggle has compared the title of an early modern play to 'a very low-resolution thumbnail based on a complex digital photograph', which despite its fuzziness proves to be invaluable in working with lost plays by virtue of its links to all the other, now unrecoverable, documents of performance. ${ }^{4}$ The aim in starting the investigation of a lost play from an intensive study of the title, as Steggle again makes clear, is 'to establish [its] meaning and to enable the play to be placed in terms of genre and other features [as] a first step towards making the play available for other sorts of discussion and for accumulation of further detail'. 5

Alfred Harbage suggested (in his Annals of English Drama) that Telomo might have been the same as Ptolome/Ptolemy, another lost play performed at the Bull Inn in the late 1570 s. ${ }^{6}$ Harbage probably based this identification on John Payne Collier's conjecture, which relied on a supposed similarity between the spellings of the two titles: in other words, 'Telomo' would simply be an alternative spelling for 'Ptolome'. ' Collier's, and then Harbage's, unwarranted conjecture has to be contextualized in light of the tendency to 'lump' together discrete play-titles that dominated theatre history in the first half of the twentieth century. ${ }^{8}$ On the one hand, such an approach bespoke a desire to combine the unknown with the known (in this particular case the assumption that Ptolemy was about an Egyptian king) as well as providing lumpers with a convenient simplification of the information at their disposal; on the other, however, the practice of lumping seriously threatened 'the complete effacement of what is sometimes the only documentary evidence testifying to the one-time existence of a play'?

Martin Wiggins argues that the identification of Telomo with Ptolemy poses a few problems, on the grounds that by 1583 the latter would have probably been too old to be staged before the queen. ${ }^{10}$ As I will show later, however, its age is not the only reason. Wiggins also suggests that Telomo may have had some connection with the romance Palmerin d'Oliva, in which 'Ptolome' is one of the main character's friends. In that case, however, the link would be to the original Spanish (1511) or the French translation (1546) rather than to Anthony Munday's English rendition, which was not published until 1588. Wiggins mistakenly gives 1581 as the date of publication of the English Palmerin d'Oliva, which is actually the year when one of the other romances in the Palmerin cycle, Palmerin of England, was entered into the Stationers' Register. However, Palmerin of England features no character named Ptolome. Coincidently, the character's name in the 
Spanish Palmerin de Oliva is 'Tolomé', which is indeed quite close to 'Telomo'. I concur with Wiggins regarding the unlikelihood of Telomo being the same play as Ptolemy; however, I find it as much unlikely that the play may have been about a secondary character of a Spanish romance that had not yet been translated into English.

With these considerations as my starting point, I seek first to challenge the conjecture that Telomo might have been a play about someone named Ptolemy. Then, I successively suggest that the play might have been about the mythological Greek hero Ajax Telamonius or his father, and finally that it might have dramatized a tragic episode narrated in Brian Melbancke's prose romance Philotimus (1583), the latter possibility ultimately emerging as significantly more likely than the former.

As a way to foreground the value of digital tools such as the electronic database Early English Books Online - Text Creation Partnership (EEBO-TCP) and Google Books for the exploration of the realm of lost plays, I will metaphorically avoid taking down the scaffolding, cleaning or discarding the paintbrushes, and simply presenting the result of my work after painting the building. Conversely, in the wake of Steggle's example, I will make 'a conscious effort to document [my] search strategies, rather than passing over them in silence as is the more usual convention in the discourse of literary studies. ${ }^{11}$ As part of this effort, I will also use bold print to denote search terms used on $E E B O-T C P$, even though this convention appears more usually in computer textbooks.

\section{Telomo Was Probably not about Someone Named Ptolemy}

In order to ascertain whether 'Telomo' might have actually been an early modern alternative spelling for 'Ptolemy', I set out to perform a series of 'brute force' searches in EEBO-TCP. After verifying that the most obvious search for telomo returned no results, I proceeded to search the database for telom* and ptelom*. ${ }^{*}$ These queries returned only three hits (in two records) that could be traced back to a person called Ptolemy. In both cases, the spelling was 'Ptelomy'. The first text (where 'Ptelomy' appears twice) is Marcus Junianus Justinus's Thabridgment of the Histories of Trogus Pompeius, Collected and Wrytten in the Laten Tonge, by the Famous Historiographer Iustine, and Translated into English by Arthur Goldyng (London, 1564). ${ }^{13}$ The other text (where 'Ptolemy' appears only once) is Christopher Blackwood's A Treatise Concerning Deniall of Christ. ${ }^{14}$ Here, however, 'Ptelomy' occurs in a page where numerous other instances of the spelling 
'Ptolemy' occur; this result seems to go a long way in suggesting that 'Ptelomy' may have been simply a misprint.

Further queries in EEBO-TCP for tolom*, ptolom*, telem*, ptelem* did reveal that the name Ptolemy (mostly referring to either a member of the dynasty that ruled Egypt from 305 to 30 в well-known astronomer) was indeed susceptible of being spelled in a wide range of different ways. None of them, however, seems particularly similar to 'Telomo': it is extremely rare even to find the vowels in the order 'e-o-o." ${ }^{15}$ A search for tolemy returned three false hits, while queries for telemy, telemie, or telemye returned no hits at all. A search for ptelem* returned one false hit (it is actually 'Ptolemy' in the text but mistranscribed in EEBO-TCP). 'Ptolomy' emerged as the most usual way of spelling that particular proper noun, almost twice as common as the second option, 'Ptolemy'. Strikingly, apart from the three occurrences of 'Ptelomy' (the 1648 one being, as I noted, probably a mere misprint), in no other case is the first vowel '-e-' - and even in those cases, it is preceded by 'pt-' rather than ' $t-$ ', with the name ending in '-y'. In all other cases the first vowel is '-o-'.

Since the proposed identification of Telomo and Ptolome was exclusively predicated on the supposed similarity between the spellings of the two titles, the search results described above make it appear quite unlikely that Telomo was a play about someone called Ptolemy, thereby adding another, possibly stronger, argument to the one Wiggins already advanced about Telomo and Ptolemy being not one and the same play.

\section{Telomo Might Have Been about Ajax Telamonius ... or His Father}

When I had searched EEBO-TCP for telom*, that query had only returned three hits, two of which were references, respectively, to 'Ajacem Telomone' in Selected Parts of Horace, Prince of Lyricks (London, 1652) and to 'Ajax Telomon' in James Shirley's Honoria and Mammon Scene Metropolis or New-Troy: Whereunto is Added the Contention of Ajax and Ulysses for the Armour of Achilles (London, 1659). ${ }^{16}$ This result suggested that the name 'Telamon' could — albeit quite uncommonly be written as 'Telomon'; thus, if we allow for the possibility that the Revels Office scribe may have forgotten the final '- $n$ ' (or a tilde above the last '-o'), it is not impossible that Telomo could have been a play about Ajax Telamonius.

Ajax was 'the most popular play by Sophokles in the Renaissance', ${ }^{17}$ and Ajax himself, arguably second only to Achilles among the Greek heroes, was a very popular figure on the early modern English stage. ${ }^{18}$ A number of contextual factors would seem to strengthen the possibility that Telomo may have been about 
Ajax. First, as a very basic EEBO-TCP search for telamon makes apparent, Ajax was indeed occasionally referred to simply as 'Telamon', most notably in William Shakespeare's Antony and Cleopatra (1606-07). ${ }^{19}$ In addition, subjects related to the Trojan War remained popular onstage throughout the Elizabethan era. ${ }^{20}$ Finally, an English translation of the first ten books of the Iliad by Arthur Hall had been published in 1581, only two years before the performance of Telomo.

If it was indeed a play about Ajax, Telomo might have staged some of his military feats as narrated in the Iliad, or could have portrayed the well-known contest between Ajax and Ulysses for the arms of the dead Achilles, also dramatized in Sophocles's Ajax and probably in the lost Ajax and Ulysses and Ajax Flagellifer, as well as narrated in Pindar's Nemeans (7, 8), Ovid's Metamorphoses (12.62013.398) and the Bibliotheca of Pseudo-Apollodorus (III.11-V.7). In his entry for Ajax and Ulysses, Wiggins usefully summarizes Ovid's version of the episode:

Ajax and Ulysses both covet the armour of the dead Achilles. The Greek army meets to decide the relative merits of their claims. Ajax asserts the virtue of his valour and high birth, and accuses Ulysses of cowardice and crafty cunning. Ulysses points out that his cunning was the only reason the Greek army had Achilles in the first place, rebuts Ajax's charges, and declares his superiority. Ulysses' eloquence wins him the armour, but Ajax takes Achilles' sword and uses it to commit suicide. ${ }^{21}$

Sophocles's play even contained more dramatically usable material; there, after Achilles's arms are awarded to Odysseus, Ajax feels so hot burning with anger that he would kill Agamemnon and Menelaus. Athena intervenes by clouding his mind and vision, so that Ajax slaughters a flock of sheep, imagining it includes Odysseus and Agamemnon. When he recovers his reason and realizes what he has done, Ajax decides he would rather commit suicide than live in shame. $\mathrm{He}$ therefore kills himself with the sword he had received from Hector as a gift. From his blood springs a red flower bearing on its leaves the initial letters of his name, 'Ai', which also express lament.

The hypothesis that Telomo dramatized Ajax's madness and suicide is tempting, but numerous problems attach to it. The first and most significant obstacle is that it appears extremely difficult to find a plausible reason why the play would have been titled 'Telamon' rather than 'Ajax' in the light of the popularity of the character, who was far more usually referred to by his first name than by the shortened form of his patronymic. At best, calling the play 'Telamon' might have confused an audience; at worst, it might have been misleading. Secondly, Ajax and Ulysses had been performed at court in 1572 and, even though ten years is by 
no means a short period of time, it does not seem particularly likely that Leicester's Men would have brought to court a play on a subject that had already been staged in front of the queen ten years earlier. ${ }^{22}$ Finally, while we know little about Leicester's Men's repertory, a play about Ajax would not sit very comfortably among the other play titles we know, which seem to point to a repertory mostly featuring romance, pastoral themes, and morally instructive contents - a point with which I will deal in further detail later after examining a further potential (and seemingly more likely) identification for the play.

Before doing so, however, I note that if Telomo was a play about someone named Telamon, it could also theoretically have been about Ajax's father, Telamon of Salamis, a small number of references to whom are returned by a search for telamon in EEBO-TCP. Telamon himself was a quite well-known mythological figure: he had been one of the Argonauts, had taken part in the Calydonian Boar hunt, and had assisted Heracles in his expeditions against the Amazons and against Troy.

Interestingly enough, Telamon was the titular character of the tragedy Telamo by Roman poet Quintus Ennius (239-169 BCE), of which only a few fragments survive. Ennius's play apparently focused on Telamon's sorrowful reaction to his son's death and the subsequent banishment of Ajax's stepbrother Teucer for failing to bring Ajax back home after the Trojan War. ${ }^{23}$

That being said, however, the possibility that Telomo was about Ajax's father does not strike me as particularly likely, insofar as in most adventures in which he takes part Telamon is usually a background character; moreover, there is no evidence available in the surviving play-texts suggesting that, as a mythological figure, he raised any significant interest in early modern English playwrights, nor does there seem to be any particular contextual reason why Leicester's Men should have chosen him as a subject for a play to be performed at court.

\section{Telomo More Likely Drew upon a Recent Romance}

On the strength of the fact that 'Telomo' may have been a misspelling of 'Telamon', I then tried running a search for telamo, without the final '- $n$ '. Among the seven hits up to 1615 that this EEBO-TCP query returned, six were either to Ajax or his father Telamon; one, however, was to an obscure text by Brian Melbancke entitled Philotimus. The Warre betwixt Nature and Fortune, published in 1583, where the name of one of the characters, Telamon, is once spelled 'Telamō'. Needless to say, this book immediately attracted my attention. 
Brian Melbancke graduated BA from St John's College, Cambridge, in 1579. Although he describes himself as a 'Student in Graies Inn' on the title page of Philotimus, his name does not appear on the records of that society. ${ }^{24}$ Philotimus. The Warre betwixt Nature and Fortune is an early euphuistic, extremely derivative romance narrating the story of Philotimus, the oldest of the twelve children of Cleocritus, governor of Mantua, and his wife Castibula, daughter of the duke of Bononia. As the only editor to date of the romance, Arthur Leroy Colby, acknowledges,

The plot of Philotimus is little more than an account of the successive disasters that overcome the hero and of the way he meets them. He loves and is rejected; he loses all of his brothers and sisters (except one), his father, and his mother; he becomes impoverished; his friends (except one) desert him; his temporarily restored substance is stolen from him. At the end ... he is restored to good fortune .... Yet the melodramatic nature of the narrative ... develops logically and smoothly, interrupted only once by the interpolated Castibula-Telamon episode. ${ }^{25}$

The story of Philotimus is arguably not in the least interesting in relation to Leicester's Men's lost Telomo, but it looks like the episode of 'The Vnkindly Loue of Telamon to Castibula His Frends Wife' might be. ${ }^{26}$ Colby labels it 'interpolated' because it is in fact, 'with little more than the names changed, an adaptation of ... the [Sinorix and] Camma story' as narrated by George Pettie in A Petite Pallace of Pettie His Pleasure (1576). ${ }^{27}$

Colby usefully summarizes the storyline of this inset narration as follows:

Telamon ... has conceived an illicit passion for Castibula .... He pursues her, but she vigorously rejects him, and eventually Telamon agrees to say no more to her of the matter. But he hires two cutthroats to murder Cleocritus. Suspecting the truth, Castibula first bewails her husband's death then swears to avenge his murder. She agrees to marry Telamon, but at the marriage feast they both drink from a poisoned cup she has prepared. Telamon retires to die; Castibula commends [her daughter] Fulvia to Philotimus' care, Philotimus to [his tutor] Mondaldo's care, and after praying for forgiveness of her double sin of murder and suicide, she dies. ${ }^{28}$

A formidable dramatic potential is inherent in this story. Extremities of passion, burning carnal desire, unrequited love, deception, murder, revenge, suicide, orphanage: the matter of Telamon and Castibula would have made a terrific subject for a play to be staged in the Elizabethan period, with the added bonus of 
the story's focus on an unshakeable model of chastity and its evident potential for being framed as a cautionary tale against the sinfulness of illicit passions that usurp the sovereignty of reason and ultimately threaten the disruption of the social fabric and the disgregation of its pillar concordia. The fact that the 'courtship' sequence was almost completely composed of ready-made lines of dialogues between the two characters rendered the episode even more readily adaptable for the stage.

Melbancke published Philotimus - a text upon which Thomas Nashe would draw too in The Anatomy of Absurdity (1589) ${ }^{29}$ — in the same year in which Leicester's Men performed Telomo at court, but he had apparently long completed his romance. The dedicatory epistles to Philip Howard, earl of Arundel, and to the gentlemen students in the Inns of Court and the University of Cambridge indicate that the book was well ready for publication on 28 November. ${ }^{30}$ Despite there being no notice of the book in the Stationers' Register, Ralph Maud has persuasively argued that the date of the dedications was probably 28 November 1582 rather than 1583.31

Maud's conclusion takes into account a number of solid pieces of evidence. First, the Trinity College, Cambridge, copy of the book bears the date 1582 rather than 1583 on its title-page. Second, 28 November 1583 as the date of the dedications beggars belief, because by that time Philip Howard was suspected of treason (and would be put under house arrest on 20 December 1583): at such a time Melbancke's possible dedication of Philotimus to him seems therefore highly unlikely. Then, a scrutiny of the sources of the romance, which scholars have hunted indefatigably and listed in detail in a series of articles published between 1929 and 1939, lends further support to Maud's assertion. ${ }^{32}$ Apparently, the latest recognizable sources are Hall's aforementioned translation of the Iliad, which appeared in 1581, and Stephen Batman's edition of Bartholomew the Englishman's De Proprietatibus Rerum, which was registered in an unprinted state on 12 March 1581/2. As Maud suggests, 'Since the observed borrowings from Batman begin on signature G, about one-fifth of the way through Philotimus, most of the novel must have been written after the middle of March 1581/2 - but not long after, since if Melbancke had lingered over his plagiarizing of Batman we would have expected him to pick up other suitable sources meanwhile'. ${ }^{33}$ Hence, at least some credit must be probably given to Melbancke's claims that he had 'beene pregnant ... almost double the time of a woman's account' with his romance and that 'Phylotimus hath beene longer in publishing then in compiling, and lesse time in penning then in printing', and they should not be utterly dismissed as mere instances of conventional authorial self-depreciation. ${ }^{34}$ 
Philotimus is therefore likely to have been penned by Melbancke as early as spring 1582, to have been approaching publication on 28 November, and possibly to have been printed by the end of December of that same year. If this sequence occurred, Leicester's Men or, more probably, one or more playwrights collaborating with them at the time may well have consulted a manuscript draft of Philotimus in advance of publication - or even the actual volume just hot off the press - and then decided to draw upon it for Telomo.

Such a scenario would not have been so unusual at the time. Close relationships between the people at the Inns of Court and the world of the professional theatre were by no means uncommon. In the specific situation under scrutiny here, the scenario becomes even more credible in the light of the fact that the family of Robert Dudley, earl of Leicester, had been associated with the Inns of Court for two generations. ${ }^{35}$ His grandfather, Edmund Dudley, had been a member of Gray's Inn. As for Robert himself, he had been chosen in 1561 by the lawyers of the Inner Temple as their Christmas Lord. He had therefore collaborated with the gentlemen of both the Inner Temple and Gray's Inn in January 1562 to set up a masque, Desire and Lady Beauty, and the tragedy Gorboduc by Thomas Norton and Thomas Sackville. ${ }^{36}$ Dudley had also used the players of Gray's Inn for a court performance at Whitehall before the queen in March 1565. The play revolved on a debate between Juno and Diana on the issue of marriage, with Jupiter adjudicating in favour of matrimony. Juno and Diana were also supposed to figure prominently in the masque prepared by George Gascoigne, a gentlemen of Gray's Inn himself, as the culmination of the Royal Entertainment at Kenilworth Castle in 1575, possibly 'the most celebrated royal visit of the entire reign', organized by the earl of Leicester as a renewed attempt to court Elizabeth. ${ }^{37}$ Supposed to be performed on 20 July, however, Gascoigne's masque had to remain confined to the page.

Interestingly, the text of Gascoigne's masque provides a tantalizingly suggestive piece of evidence that may further contribute to supporting the identification of Telomo as a play drawing upon the episode of Telamon and Castibula in Philotimus, namely the fact that a nymph named Castibula curiously appears in Gascoigne's masque as a strong advocate of Zabeta/Elizabeth's chastity in the face of the designs of Juno, who in fact

with some gorgeous gift,

Hath layde some snare hyr fancie to entrap, And hopeth so hyr loftie mynde to lyft On Hyme $[n]$ s bed, by height of worldly hap. ${ }^{38}$ 
Gascoigne's and Melbancke's are the only known uses of a character named Castibula (literally, either 'the place of chastity' or 'the instrument of chastity') in early modern English literature. A search for castibula in EEBO-TCP, however, strangely returns no results apart from those in Melbancke's romance. This misinformation is due to the fact that The VVhole Woorkes of George Gascoigne Esquire (London, 1587), albeit present in EEBO, has not been included in EEBO-TCP yet. ${ }^{39}$ It was only by searching for castibula in Google Books that I was able to unveil this potential connection.

The use of the same name for a character (a mere background character in Gascoigne while a main one in Melbancke) is not in itself proof of anything. Colby has established that Melbancke generously drew upon Gascoigne's works for several passages in his Philotimus - the name of the titular character itself might come from Gascoigne's own Glasse of Government, which features a speaker called Philotimus. ${ }^{40}$ That being said, Melbancke's decision to lift the name of a nymph advocating chastity for Zabeta/Elizabeth in an unperformed masque commissioned by the earl of Leicester and written by a gentleman of Gray's Inn is nonetheless quite striking.

Whatever the precise circumstances behind Melbancke's choice, however, the ramified network of relationships tying together the Inns of Court, the earl of Leicester, and his players should be evident, thereby lending something more than mere plausibility to a scenario in which one or more playwrights working with Leicester's Men read the story of Telamon and Castibula in summer 1582 or shortly thereafter in manuscript, possibly following a suggestion by Robert Dudley, who had been often involved directly in the production of diverse forms of entertainment, as we have seen.

If Telomo was indeed a play about Telamon and Castibula, then the choice of the male protagonist as the titular character might suggest that there may have been (at least nominally) a primary focus on Telamon's sinful desire and deserved punishment rather than on Castibula's admirable resistance to her immoral suitor's amorous offers, her sorrow for her husband's death, and her premeditated murder-suicide to avenge herself on Telamon.

If the stage Telamon was similar to his prose counterpart, he might have fit the concise description of the character of the romance offered by Colby, whose words I again find expedient generously to quote:

Telamon ... is a courtly lover .... His passion for Castibula, nourished and maintained in secrecy, grows rapidly and becomes overwhelming. His physical desire for her is cloaked in speeches of elegant refinement, and his attitude toward the 
near-deified Castibula is self-abasing and reverent. He regards Castibula's continued coldness to his suit as a trial to be undergone in demonstration of the worthiness of his affection. Yet the love itself, for all its outwardly spiritual manifestation, is still a potentially adulterous one, and Telamon's position is a morally and ethically untenable one. ${ }^{41}$

Telamon's passion for Castibula, Colby adds, is portrayed as 'a tripartite treason: against Castibula, against his friend, and against himself'. ${ }^{42} \mathrm{His}$ passion is therefore morally reprehensible under every possible point of view and cannot but deserve just retribution. As for Castibula, the narrative celebrates her as a surpassing model of chastity, honest love, and faithfulness, and I concur with Colby's statement that her 'rather melodramatic conduct in the Telamon episode ..., though [possibly] stretching the bounds of credibility, is nonetheless consistent with her presentation as a faithful wife. ${ }^{43}$

Thus, if Leicester's Men had indeed chosen to dramatize that story, they might have framed the plot so as to underscore the smarmy duplicity and lewd immorality of Telamon's coveting his friend's wife, on the one hand, while at the same time glorifying Castibula's adamantine, unassailable chastity, on the other. Such a choice would have possibly been a way to pander to the cult of chastity favoured by the queen, especially inasmuch as 'Castibula demonstrates that her chastity ... is not the easy virtue possible to the untempted but the great virtue possible only to the greatly tempted, and thus a type of the virtue personified ... by Queen Elizabeth herself. ${ }^{44}$ If Melbancke intended the role of Castibula as some sort of homage to the queen, arguably that depiction would have been at some remove from Dudley's previous insistent attempts at convincing Elizabeth to marry him, possibly in the light of his recent marriage with Lettice Knollys, Lady Essex, a union which the queen never approved of and which seems to have put quite a strain on their relationship. ${ }^{45}$ In other words, the play might have been part of an attempt on Dudley's part somehow to appease the queen's hostility to his new wife and him. If this had been the case, such an homage would nonetheless have been somewhat oblique, inasmuch as Castibula is married with children. The oblique character of this hypothetical homage, however, does not invalidate the present argument, just as the fact that Britomart, knight of Chastity, eventually marries Artegall and bears children does not preclude the possibility of seeing Britomart's chastity as a homage to Elizabeth in Edmund Spenser's The Faerie Queene (1590-96). In the sixteenth century the concept of chastity did not simply stand for the abstention from intercourse; it could also describe an unblemished 
love for one person, a love which could include marriage, sex, and children. For Britomart, that one person was Artegall; for Castibula, Cleocritus.

Admittedly, the addition of a dramatization of the classically inspired, Italianate-derived novella of Telamon and Castibula to Leicester's Men's repertory would to some extent go against conventional wisdom about said repertory, which included such titles as Predor and Lucia (1573), Mamillia (1573), Panecia (1574), Philemon and Philecia (1574), The History of the Collier (1576), Mingo (1577), possibly The Blacksmith's Daughter (1578), A Greek Maid (1578), and Delight (1580). To these one could add The Three Ladies of London (1581, if its playwright, R.W., was indeed their Robert Wilson) and The Story of Samson (1567, if the company played at the Red Lion in that period, which is plausible). ${ }^{46}$ These titles, as Roslyn L. Knutson argues, 'suggest a repertory like those of the boy companies in its romances and moral plays, broadened by the inclusion of biblical subjects and folk or estate characters'. ${ }^{47}$ However, the Telamon-Castibula plot seems more lamentably tragic and somehow less light-hearted than the narratives apparently implied by the other titles - albeit still uncontroversial enough not to upset the queen during the festivities, while at the same time effectively celebrating that ideal of chastity that was so nuclear to her persona and that she so strongly upheld. Even though identifying with any degree of certainty the actual content of Leicester's Men's plays that we know of only through their titles is exceedingly difficult — if not impossible - assuming that they mainly focused on pastoral and classical themes in keeping with 'the classical and romance veins associated with humanism' that characterized the period seems safe enough. ${ }^{48}$ In this sense, the identification of the episode of Telamon and Castibula as a probable narrative source for Telomo would show that the plays in Leicester's Men's repertory possibly also encompassed themes other than romance and biblical subjects, and did not refrain from using intense stage ingredients with a view to moral edification.

Moreover, while potentially expanding the scope of Leicester's Men's repertory, this identification would also have the merit of locating this play in a major trend discernible in the group of performances mounted at court around 1580, namely a taste for plays with an Italianate setting such as Warwick's Men's The Three Sisters of Mantua (1578), Sussex's Men's The Duke of Milan and the Marquis of Mantua (1579), Ariodant and Jenevora (1583) by the boys of the Merchant Taylors' School, the earlier Gismond of Salern (1568) by the Gentlemen of the Inner Temple, or the latter's much later revised version Tancred and Gismund (1591) - possibly the very trend that was openly criticized by Stephen Gosson, who lamented 'that the Palace of pleasure, the Golden Asse, the Athiopian historie, Amadis of Fraunce, the Rounde table, baudie Comedies in Latine, French, Italian, and Spanish, haue beene 
throughly ransackt, to furnish the Playe houses in London', filling them with 'lyes, cosenages, baudries, whooredemes'. ${ }^{49}$ The story of Telamon and Castibula would not only feature or be set in Mantua as the aforementioned The Three Sisters of Mantua and The Duke of Milan and the Marquis of Mantua; it would also fit perfectly side by side with Ariodante and Jenevora, which is mentioned in the same Revels Account that mentions Telomo and which also features unrequited love, conflicting passions, violent deaths, subterfuge, jealousy and the villain's hiring of a couple of murderers to kill his rival.

\section{Informed Conjecture}

In this article I have first argued that Telomo may hardly have been a play about a character named Ptolemy by challenging the affinity between the spellings 'Telomo' and 'Ptolome' suggested by previous scholars. Then, I have examined the possibility that the play may have been about Ajax Telamonius or his father, which appears, however, not very likely for a number of reasons. Finally, I have proposed that Telomo may have dramatized the story of Telamon and Castibula as narrated in Brian Melbancke's Philotimus.

Needless to say, the proposal brought forward in these pages - like most arguments about lost plays - must necessarily rely to a large extent on conjectures, however sensible and informed they may be: Misha Teramura voices a common concern when he wonders, 'can there be criticism without a text?. ${ }^{50}$ As Steggle remarks, 'one must always remember that the evidence base is ... much smaller and more vulnerable than for a play whose playscript is extant.'. ${ }^{51}$ As a result, 'Telomo' might simply have been a different character entirely, now utterly unknown to us, completely lost in the mists of time. In this sense, this article stands as a further exemplification of the potentialities as well as the as-yet insurmountable limits inherent in this new sub-field of early modern studies. Most scholarly efforts regarding lost plays have to reckon with the fact that any conclusions cannot but remain provisional and open to successive discussion and discovery, because we cannot reach absolute certainty.

Yet, as Andrew Gurr argues, 'every little act of retrieval helps, and the full picture ... needs every small detail we can acquire for it.'. 52 Despite its inherent and irresoluble limitations, the discussion of lost plays can nonetheless be a valuable area of scholarship in terms of the insights it provides — however limited they may be - into the practices and repertories of early modern playing companies, especially inasmuch as 'identifiable lost plays are significantly more numerous than extant ones': the latest and most authoritative count by Wiggins provides a 
picture where, among the ca 3,000 different plays written and staged in England between 1567 and 1642, 543 survive, 744 are identifiable as lost, and over 1,700 can be classified as 'gone'. 53 In this particular case, accepting the identification of the Telamon-Castibula storyline as the subject of Telomo may on the one hand lead to a slightly more nuanced understanding of Leicester's Men's repertory as also including plots drawing upon novelle with an Italianate setting featuring violent elements with a view to providing the audience with edifying moral lessons or cautionary tales; on the other hand, this identification may also contribute to strengthening current notions regarding the main theatrical trends affecting the choice of subjects for court performances ca 1580, among which plays with an Italianate setting seem to have been quite a regular presence.

\section{Notes}

This article draws upon research I performed in June-July 2016 as visiting scholar at Sheffield Hallam University, where I was able to access EEво-TCP Phase II. I would like to thank Roslyn L. Knutson, Matthew Steggle, and Luisa Villa for generously commenting on an earlier version of this article. I am also grateful to Early Theatre's two anonymous reviewers for their valuable suggestions.

1 Albert Feuillerat, Documents Relating to the Office of the Revels in the Time of Queen Elizabeth (Louvain, 1908), 350.

2 Sally-Beth MacLean, 'Tracking Leicester's Men: The Patronage of a Performance Troupe', Paul Whitfield White and Suzanne R. Westfall (eds), Shakespeare and Theatrical Patronage in Early Modern England (Cambridge, 2002), 261-2.

3 Matthew Steggle, Digital Humanities and the Lost Drama of Early Modern England: Ten Case Studies (Farnham, 2015), 2, 19, http://dx.doi.org/10.4324/9781315577180.

4 Matthew Steggle, 'Lost, or Rather Surviving as a Very Short Document', David McInnis and Matthew Steggle (eds), Lost Plays in Shakespeare's England (Basingstoke, 2014), 80, 78, http://dx.doi.org/10.1057/9781137403971_5.

5 Steggle, Digital Humanities and the Lost Drama of Early Modern England, 8.

6 See 'Ptolemy', in Roslyn L. Knutson, David McInnis, and Matthew Steggle (eds), Lost Plays Database (Melbourne, 2009-), https://www.lostplays.org/index. php?title=Ptolemy.

7 John Payne Collier, 'History of the English Drama and Stage to the Time of Shakespeare', Shakespeare's Comedies, Histories, Tragedies, and Poems, 6 vols (London, 1858), 1.22; Alfred Harbage, Annals of English Drama, 975-1700 (Philadelphia, 1940), 52, http://dx.doi.org/10.4324/978020376963. 
8 See John H. Astington, 'Lumpers and Splitters', McInnis and Steggle (eds), Lost Plays in Shakespeare's England, 84-102, http://dx.doi.org/10.1057/9781137403971_6.

9 David McInnis and Matthew Steggle, 'Introduction: Nothing Will Come of Nothing? Or, What Can We Learn from Plays that Don't Exist?', McInnis and Steggle (eds), Lost Plays in Shakespeare's England, 5, http://dx.doi.org/10.1057/9781137403971_1.

10 Martin Wiggins, in association with Catherine Richardson, British Drama 15331642: A Catalogue, 10 vols (Oxford, 2012-), 2:\#736. See also the entry 'Telomo', in Knutson, McInnis, and Steggle (eds), Lost Plays Database, https:/www.lostplays.org/ index.php?title=Telomo .

11 Steggle, Digital Humanities and the Lost Drama of Early Modern England, 26. All searches are implicitly dated to July 2016.

12 The * is a wildcard that can stand for any value, so that, for example, telom* is effectively an instruction: 'Include all the words that begin with the string telom followed by none, or one, or many characters'.

13 Marcus Junianus Justinus, Thabridgment of the Histories of Trogus Pompeius, Collected and Wrytten in the Laten Tonge, by the Famous Historiographer Iustine, and Translated into English by Arthur Goldyng: a worke conteynyng brieflie great plentie of moste delectable hystories, and notable examples, worthie not onelie to be read but also to be embraced and followed of all menne (London, 1564; sTC: 24290).

14 Christopher Blackwood, A Treatise Concerning Deniall of Christ: A subject of most high concernment for all those who intend to follow Christ (London, 1648; Wing: B3104).

15 The various spellings are (in order of frequency): 'Ptolomy' (6,385 matches in 1,084 records), 'Ptolemy' (3,337 matches in 388 records), 'Ptolomie' (1,776 matches in 396 records), 'Ptolomeus' (1,707 matches in 481 records), 'Ptolomey' (1,480 matches in 247 records), 'Ptolemie' (1,070 matches in 79 records), 'Ptolome' (1,057 matches in 209 records), 'Ptolemey' (325 matches in 54 records), 'Ptolemeus' (213 matches in 104 records), 'Ptolomye' ( 42 matches in 15 records), 'Ptolomeo' (23 matches in 21 records), 'Ptoleme' (23 matches in 17 records), 'Ptolemye' (20 matches in 2 records), 'Tolomeo' (17 matches in 11 records), 'Tolomeus' (11 matches in 5 records), 'Tolomy' (9 matches in 9 records), 'Tolomey' (9 matches in 6 records), 'Ptolemeo' (6 matches in 6 records), 'Tolome' ( 6 matches in 6 records), 'Tolomie' (5 matches in 5 records), 'Tolomye' (1 match in 1 record).

16 Selected Parts of Horace, Prince of Lyricks; and of all the Latin poets the fullest fraught with excellent morality. Concluding with a piece out of Ausonius. and another out of Virgil. Now newly put into English (London, 1652; Wing: H2786), 18; James Shirley, Honoria and Mammon Scene Metropolis or New-Troy: whereunto is added the Contention of Ajax and Ulysses for the armour of Achilles (London, 1659, 118; Wing: S3473), 118. 
17 Ian Christopher Storey and Arlene Allan, A Guide to Ancient Greek Drama (Malden, 2005), 115, http://dx.doi.org/10.1002/9780470776209.

18 He appeared in the lost Ajax and Ulysses (performed by the Children of Windsor at court in 1572), Henry Chettle and Thomas Dekker's lost Troilus and Cressida (1599), William Shakespeare's Troilus and Cressida (1602), the lost Latin Ajax Flagellifer (performed at Christ Church, Oxford, on 28 August 1605 by players from Magdalen College, for a royal visitation), Thomas Heywood's 1 The Iron Age (1612-32), and Shirley's aforementioned Contention of Ajax and Ulysses for the Armour of Achilles (1640).

19 William Shakespeare, Antony and Cleopatra, 4.14.1-3, in Gary Taylor, John Jowett, Terri Bourus and Gabriel Egan (eds), The New Oxford Shakespeare: The Complete Works: Modern Critical Edition (Oxford, 2016), 2638: 'Cleopatra Help me, my women! O, he's more mad / Than Telamon for his shield; the boar of Thessaly / Was never so embossed'.

20 John Strong Perry Tatlock, 'The Siege of Troy in Elizabethan Literature, Especially in Shakespeare and Heywood', Publications of the Modern Language Association of America 30 (1915), 676-8, http://dx.doi.org/10.2307/456975.

21 Wiggins, British Drama 1533-1642: A Catalogue, 2.\#500.

22 Although it could theoretically be argued that while the 1572 play may have drawn upon Ovid, the 1583 one may have used Sophocles as a source, possibly in Greek, or in a Latin or French translation (the first English translation would not be published until 1714).

23 Franco Caviglia, 'Il Telamo di Ennio', Annali della Scuola Normale Superiore di Pisa. Lettere, Storia e Filosofia, 2nd ser., 39 (1970), 469-88.

24 Bertha Porter, 'Brian Melbancke', Dictionary of National Biography (DNB), 63 vols (Oxford, 1885-1900), 37.216.

25 Arthur Leroy Colby, 'Brian Melbancke's Philotimus (1583): A Critical Edition', PhD Thesis (University of North Carolina at Chapel Hill, 1969), lv.

26 Brian Melbancke, Philotimus. The Warre betwixt Nature and Fortune (London, 1583; STC: 17801), ЕЕВо, 99-117.

27 Colby, 'Brian Melbancke's Philotimus', xiii. The story was first told by Plutarch in De Mulierum Virtutibus and the Eroticus sive Amatorium.

28 Colby, 'Brian Melbancke's Philotimus', xlix.

29 Ronald Brunlees McKerrow (ed.), The Works of Thomas Nashe, 5 vols (London, 1904-10), 5:122.

30 Melbancke, Philotimus, $\pi 3^{\mathrm{a}}, \pi 4^{\mathrm{a}}$.

31 Ralph Maud, 'The Date of Brian Melbancke's Philotimus', The Library s5-11 (1956), 118-20, http://dx.doi.org/10.1093/library/s5-XI.2.118. 
32 Hyder Edward Rollins, 'Notes on Brian Melbancke's Philotimus', Studies in Philology, Extra Series 1 (1929), 40-57; 'Notes on the Sources of Melbancke's Philotimus', Harvard Studies and Notes in Philology and Literature 18 (1936), 177-98; 'Thomas Deloney and Brian Melbancke: Notes on Sources', Harvard Studies and Notes in Philology and Literature 19 (1937), 219-29; Morris Palmer Tilley, 'Further Borrowings from Poems in Philotimus (1583)', Studies in Philology 27 (1930), 186-214; Don Cameron Allen, 'Melbancke and Gosson', Modern Language Notes 54 (1939), 11114. See also the examination of sources in Colby, 'Brian Melbancke's Philotimus', vii-xviii.

33 Maud, 'The Date of Brian Melbancke's Philotimus', 119.

34 Melbancke, Philotimus, $\pi 3^{\mathrm{b}}$.

35 The following discussion on Robert Dudley is variously indebted to MacLean, 'Tracking Leicester's Men: The Patronage of a Performance Troupe'; Clare Rider, 'Lord Robert Dudley, "chief patron and defender" of the Inner Temple', https://www. innertemple.org.uk/history/historical-articles/30-lord-robert-dudley ; Arthur F. Kinney, 'The Sidneys and Public Entertainments', Margaret Patterson Hannay, Michael G. Brennan, and Mary Ellen Lamb (eds), The Ashgate Research Companion to the Sidneys, 1500-1700, 2 vols (Farnham, 2015), 1.241-59; Paul Whitfield White, 'Patronage, Protestantism, and Stage Propaganda', Cedric Clive Brown (ed.), Patronage, Politics, and Literary Traditions in England, 1558-1658 (Detroit, 1993), 111-24.

36 Both works have been perceptively examined in relation to their political valences by Marie Axton, 'Robert Dudley and the Inner Temple Revels', Historical Journal 13 (1970), 365-78, http://dx.doi.org/10.1017/s0018246x00009237. Axton suggests that the masque was probably designed by Dudley to court Elizabeth and convince her to marry him.

37 White, 'Patronage, Protestantism, and Stage Propaganda', 121.

38 George Gascoigne, The Princely Pleasures at Kenelworth Castle, in The Complete Works of George Gascoigne, ed. John William Cunliffe, 2 vols (Cambridge, 1907-10), 2.110 .

39 The VVhole Woorkes of George Gascoigne Esquire: newlye compyled into one volume, that is to say: his Flowres, hearbes, weedes, the fruites of warre, the comedie called Supposes, the tragedie of Iocasta, the Steele glasse, the complaint of Phylomene, the storie of Ferdinando Ieronimi, and the pleasure at Kenelworth Castle (London, 1587; STC: 11638).

40 George Gascoigne, The Glasse of Government, in The Complete Works, 2:35-56. Colby, 'Brian Melbancke's Philotimus', xvii, counts at least 38 borrowings from Gascoigne in Melbancke's Philotimus.

41 Colby, 'Brian Melbancke's Philotimus', lxxix. 
42 Ibid, lxxx.

43 Ibid, liv.

44 Ibid, lxxx.

45 See Elizabeth Jenkins, Elizabeth and Leicester (New York, 1961), 247, 279-80, 305; Derek Wilson, Sweet Robin: A Biography of Robert Dudley Earl of Leicester 1533-1588 (London, 1981), 228, 230-1, 247; P.E.J. Hammer, The Polarisation of Elizabethan Politics: The Political Career of Robert Devereux, 2nd Earl of Essex, 1585-1597 (Cambridge, 1999), 46; Derek Wilson, The Uncrowned Kings of England: The Black History of the Dudleys and the Tudor Throne (New York, 2005), 358.

46 Roslyn L. Knutson, 'Playing Companies and Repertory', Arthur F. Kinney (ed.), A Companion to Renaissance Drama (Malden, 2002), 181, http://dx.doi. org/10.1002/9780470998922.ch14; Knutson, McInnis, and Steggle (eds), Lost Plays Database, https://www.lostplays.org/lpd/Category:Leicester's. Margaret Shewring, 'Repertoire of the Professional Players in Stratford-upon-Avon, 1568-1597', James Ronald Mulryne (ed.), The Guild and Guild Buildings of Shakespeare's Stratford: Society, Religion, School and Stage (Farnham, 2012), 234-5, adds that 'Leicester's Men may also have owned two plays by Stephen Gosson, thought to have been written in the 1576-7 period: Captain Mario, a 'Comedy', and Praise at Parting, a 'Moral' play. Both are thought to have been performed by Leicester's Men at James Burbage's playhouse, the Theatre - but not until 1581-2. Two further plays, thought to have been written between 1576 and 1579, [might have been] in the repertoire of Leicester's in 1578: Stephen Gosson's play, Catiline's Conspiracies ... [and] The Blacksmith's Daughter'.

47 Knutson, 'Playing Companies and Repertory', 181.

48 Siobhan Keenan, Travelling Players in Shakespeare's England (Basingstoke, 2002), 158, http://dx.doi.org/10.1057/9780230597549.

49 Stephen Gosson, Playes Confuted in Fiue Actions (London, 1582; stc: 12095), D5v.

50 Misha Teramura, 'Brute Parts: From Troy to Britain at the Rose, 1595-1600', McInnis and Steggle (eds), Lost Plays in Shakespeare's England, 142, http://dx.doi. org/10.1057/9781137403971_8.

51 Steggle, Digital Humanities and the Lost Drama of Early Modern England, 10.

52 Andrew Gurr, 'What Is Lost of Shakespearean Plays, Besides a Few Titles?', McInnis and Steggle (eds), Lost Plays in Shakespeare's England, 70, http://dx.doi. org/10.1057/9781137403971_4.

53 Steggle, Digital Humanities and the Lost Drama of Early Modern England, 8-9. 